\title{
Effect of VOC Emissions from Vegetation on Air Quality in Berlin during a Heatwave
}

Galina Churkina, ${ }^{* \dagger, \ddagger \odot}$ Friderike Kuik, $^{\dagger}$ Boris Bonn, ${ }^{\dagger, \S}$ Axel Lauer, ${ }^{\|}$Rüdiger Grote, ${ }^{\dagger, \perp}$ Karolina Tomiak, ${ }^{\dagger}$ and Tim M. Butler ${ }^{\dagger}$

${ }^{\dagger}$ Institute for Advanced Sustainability Studies, Berliner Strasse 130, 14467 Potsdam, Germany

${ }^{\ddagger}$ Geography Department, Humboldt-Universität zu Berlin, Unter den Linden, 10099 Berlin, Germany

${ }^{\S}$ Institute for Forest Sciences, Chair of Tree Physiology, Albert-Ludwigs-Universität Freiburg, Georges-Köhler-Allee 53, 79110

Freiburg, Germany

"Deutsches Zentrum für Luft- und Raumfahrt (DLR), Institut für Physik der Atmosphäre, Münchener Straße 20, 82234 Weßling, Germany

${ }^{\perp}$ Karlsruhe Institute of Technology (KIT), Institute of Meteorology and Climate Research (IMK-IFU), Kreuzeckbahnstrasse 19, 82467 Garmisch-Partenkirchen, Germany

Supporting Information

ABSTRACT: The potential of emissions from urban vegetation combined with anthropogenic emissions to produce ozone and particulate matter has long been recognized. This potential increases with rising temperatures and may lead to severe problems with air quality in densely populated areas during heat waves. Here, we investigate how heat waves affect emissions of volatile organic compounds from urban/suburban vegetation and corresponding ground-level ozone and particulate matter. We use the Weather Research and Forecasting Model with atmospheric chemistry (WRF-Chem) with emissions of volatile organic compounds (VOCs) from vegetation simulated with MEGAN to quantify some of these feedbacks in Berlin, Germany, during the heat wave in 2006. The highest ozone concentration observed during that period was $\sim 200 \mu \mathrm{g} / \mathrm{m}^{3}(\sim 101$ $\mathrm{ppb}_{\mathrm{V}}$ ). The model simulations indicate that the contribution of biogenic VOC emissions to ozone formation is lower in June (9-11\%) and August (6-9\%) than in July (17-20\%). On particular days within the analyzed heat wave period, this contribution increases up to $60 \%$. The actual contribution is expected to be even higher as the model underestimates isoprene concentrations over urban forests and parks by 0.6-1.4 $\mathrm{ppb}_{\mathrm{v}}$. Our study demonstrates that biogenic VOCs can considerably enhance air pollution during heat waves. We emphasize the dual role of vegetation for air quality and human health in cities during warm seasons, which is removal and lessening versus enhancement of air pollution. The results of our study suggest that reduction of anthropogenic sources of NOx, VOCs, and PM, for example, reduction of the motorized vehicle fleet, would have to accompany urban tree planting campaigns to make them really beneficial for urban dwellers.

\section{INTRODUCTION}

Programs to plant millions of trees in $\operatorname{cities}^{1}$ aim at the reduction of summer temperatures (as trees increase evapotranspiration and provide shade), an increase of carbon storage, stormwater control, provision of space for recreation, as well as poverty alleviation. ${ }^{2}$ Although these benefits speak for urban greening programs, the programs do not fully account for the interactions between urban vegetation and the urban environment. Green areas in cities are exposed to elevated temperatures ${ }^{3}$ and high anthropogenic pollution of air, ${ }^{4}$ soil $^{4}$ and water. ${ }^{5}$ Furthermore, urban soils are often compacted, which is unfavorable for water availability, and are exposed to deicing substances ${ }^{6}$ harmful for vegetation growing along streets. Urban and suburban vegetation responds to changes in abiotic conditions with modifications in its physiology and anatomy. ${ }^{7}$ These changes affect not only the ability of vegetation to filter pollutants, but also its gaseous emissions and, as a result, create a feedback mechanism to ambient conditions. The gaseous emissions from vegetation can react with air pollutants enhancing pollutants' concentrations. Neglecting these interactions may lead to unforeseen drawbacks of urban greening programs.

Plants emit volatile organic compounds (VOCs), some of which are, for example, odors we can smell. VOC emissions increase during warm seasons with high insolation and especially during the flowering periods, ${ }^{9}$ often exhibiting exponential temperature dependence. ${ }^{10}$ Plants also increase

Received: January 9, 2017

Revised: April 27, 2017

Accepted: April 27, 2017

Published: May 17, 2017 
their VOC emissions in response to drought conditions ${ }^{9}$ and high concentrations of ground level ozone. ${ }^{11}$ Moreover, insect outbreaks $^{12}$ or lawn mowing ${ }^{13}$ trigger higher emissions of VOCs. VOC emissions scale with leaf area, which increases with higher $\mathrm{CO}_{2}$ concentrations, although negative responses of VOC emissions to rising concentrations of $\mathrm{CO}_{2}$ may compensate for this. ${ }^{14}$

In areas with substantial levels of nitrogen oxides $\left(\mathrm{NO}_{x}=\right.$ $\mathrm{NO}+\mathrm{NO}_{2}$ ) such as urban and suburban regions, VOCs can undergo chemical reactions leading to the formation of ozone and particulate matter (PM). ${ }^{15}$ Although plants release hundreds of different VOCs, ${ }^{16}$ only a few of them have a substantial effect on air quality. The most important reactive biogenic VOCs are isoprene, monoterpenes, and sesquiterpenes. Emissions of isoprene mostly contribute to the formation of ground level ozone, ${ }^{17}$ while monoterpenes and sesquiterpenes can lead to an increase in particle number and mass. ${ }^{18}$ While gaseous VOCs intensify ozone production, the transfer of VOCs between gas- and particle-phase can either slow down or enhance urban ozone formation. In case of high gas-phase concentrations of VOCs with more than five carbon atoms, semivolatile compounds will transition to the particle phase and will be temporarily removed from the cycle of ozone production. Recent study suggests that this process may also take place in Berlin, Germany (Boris Bonn, personal communication). If the organic PM concentration is high and air temperatures increase, organic PM will partially evaporate and may add to the ozone formation as a supplementary VOC.

Secondary organic aerosol (SOA) can contribute considerably to the mass of fine particles (smaller than $1 \mu \mathrm{m})^{19}$ and also add to the mass of particles smaller than $10 \mu \mathrm{m}\left(\mathrm{PM}_{10}\right)$, which is typically dominated by large particles $(>1 \mu \mathrm{m})$. A large fraction of SOA mass can typically be attributed to emissions of biogenic VOCs. ${ }^{20}$ Examples include studies by Tunved et al., $^{21,22}$ who showed that over forested regions in Scandinavia the aerosol mass was proportional to the duration of the air residing over the forest. Ghirardo et al. ${ }^{23}$ showed that emissions of biogenic VOCs from trees can influence ozone and particle formation in Beijing, China.

An increase in biogenic VOC emissions in response to air pollution or to rising air temperatures can influence SOA formation indirectly via enhanced concentrations and partitioning of precursors resulting in a different distribution of the particle sizes. ${ }^{24}$ In a modeling study, Megaritis et al. ${ }^{25}$ found that a temperature increase of $2.5^{\circ} \mathrm{C}$ led to a $20 \%$ increase in summertime biogenic SOA over the northern parts of Europe. The simulation of SOA formation with a numerical model is challenging, because of the large number of organic compounds relevant to the formation of organic aerosol particles, ${ }^{26}$ as well as the complex chemical pathways converting organic vapors into low-volatility compounds that can either partition onto existing organic particles (condensation) or form new particles (nucleation). ${ }^{20}$

Heat waves, which are here defined as five or more consecutive days during which the daily maximum temperature exceeds the average maximum temperature by $5{ }^{\circ} \mathrm{C}$ or more, can enhance air pollution directly and indirectly. Directly, because high temperature and solar radiation intensify photochemistry $^{27}$ and formation of oxidized and thus less volatile organic compounds, and indirectly because anthropogenic emissions associated with enhanced use of air conditioning as well as biogenic emissions of VOCs tend to increase. In addition, stable atmospheric conditions typical for hot periods lead to increased pollutant concentrations near the surface. ${ }^{28}$ Cities are more vulnerable than rural areas to heat waves, because they are warmer due to the urban heat island effect. Average annual temperatures in cities are usually higher than in surrounding areas by $1-3{ }^{\circ} \mathrm{C}$ and this difference can go up to $10{ }^{\circ} \mathrm{C}$ in summer nights ${ }^{29}$ because of, for instance, heat energy stored during the day and emitted by buildings and paved surfaces at night, low evapotranspiration from limited green space, and various anthropogenic heat sources (e.g., heat released by industrial facilities, air conditionings, etc.). During heat waves cities experience a combination of the urban heat island effect and the heat wave itself. ${ }^{30}$ For example, the heat wave in 2003 in Central Europe was accompanied by extremely high levels of ozone. In France, the highest hourly ozone value of $417 \mu \mathrm{g} / \mathrm{m}^{3}\left(\sim 210 \mathrm{ppb}_{\mathrm{V}}\right)$ was reached near Marseille. ${ }^{31}$ In the UK, high levels of air pollution rather than the heat caused $21-$ $38 \%$ of the estimated 2045 premature deaths ${ }^{32}$ related to the heat wave in 2003. During hot periods vegetation tends to reduce stomatal openings leading to decreased ozone deposition. At the same time the high temperatures can substantially increase emissions of VOCs. Using results from a field campaign in August 2003 near London, Lee et al. ${ }^{33}$ showed a rise in concentrations of isoprene from vegetation from 60 to $500 \mathrm{ppt}_{\mathrm{V}}$, when air temperature increased from 20 to $30{ }^{\circ} \mathrm{C}$ and related it to enhanced ozone concentrations $\left(>110 \mathrm{ppb}_{\mathrm{V}}\right)$. Although poor urban air quality and high VOC emissions have been documented during excessively hot periods, the relative contribution of biogenic VOC emissions to the poor air quality episodes in midlatitude cities have not been quantified.

Here, we investigate the effect of a heat wave on the emissions of VOCs from vegetation as well as on the ground level concentrations of ozone and particulate matter in the Berlin-Brandenburg metropolitan area, Germany, in 2006. This was the year of the latest well documented heat wave with significant increase in premature mortality in that area. ${ }^{34} \mathrm{We}$ compare modeled pollutant concentrations in summer 2006 with those in summer 2014, when meteorological conditions were more typical and test the sensitivity of the results to the emissions of VOC from vegetation.

\section{METHODS}

Below we describe the study domain, VOC measurements used for model evaluation, model setup, evaluation of the model's ability to simulate biogenic VOCs, as well as the model experiments to estimate the contribution of biogenic VOCs to the concentrations of ozone and particulate matter in the Berlin-Brandenburg metropolitan area, Germany.

Study Domain. The Berlin-Brandenburg metropolitan area is located in the northeastern part of Germany $\left(\sim 52.5^{\circ} \mathrm{N}\right.$, $\left.13.4^{\circ} \mathrm{E}\right)$. Berlin is the largest city in the study area with a population of 3.35 million and covering $891.7 \mathrm{~km}^{2} .{ }^{35}$ Forests (18\%), parks (13\%), and agriculture (4\%) cover $35 \%$ of the Berlin area, ${ }^{36}$ making it one of the greenest European capitals. Berlin is surrounded by the Federal State of Brandenburg, which is dominated by agriculture $(50 \%)$ and forests $(36 \%) .35$

Between July 10th and July 30th 2006, Berlin experienced a heat wave with average daily maximum temperatures well over $30{ }^{\circ} \mathrm{C}$. The highest temperature observed was $36.6{ }^{\circ} \mathrm{C}$. The highest ozone concentration observed was $\sim 200 \mu \mathrm{g} / \mathrm{m}^{3}(\sim 101$ $\mathrm{ppb}_{\mathrm{V}}$ ) (Figure $\mathrm{S} 6$ ). The average daily maximum temperatures were between 26 and $27^{\circ} \mathrm{C}$ in July 2014. The monthly mean temperature of July $2006\left(23-24{ }^{\circ} \mathrm{C}\right)$ was $\sim 4{ }^{\circ} \mathrm{C}$ higher than 
the climatological mean temperature of Berlin in July (19-20 ${ }^{\circ} \mathrm{C}$ depending on the measurement station ${ }^{37}$ ). During the 3 weeks of the 2006 heat wave, the all-cause mortality was $\sim 20 \%$ higher than the average number of deaths per day calculated over a period of 17 years $(1990-2006)^{34}$

VOC Observations. VOC concentrations were continuously measured during the BAERLIN field campaign in summer 2014 at a site located in a residential neighborhood of the Neukölln district in the center of Berlin (Figure 1). In

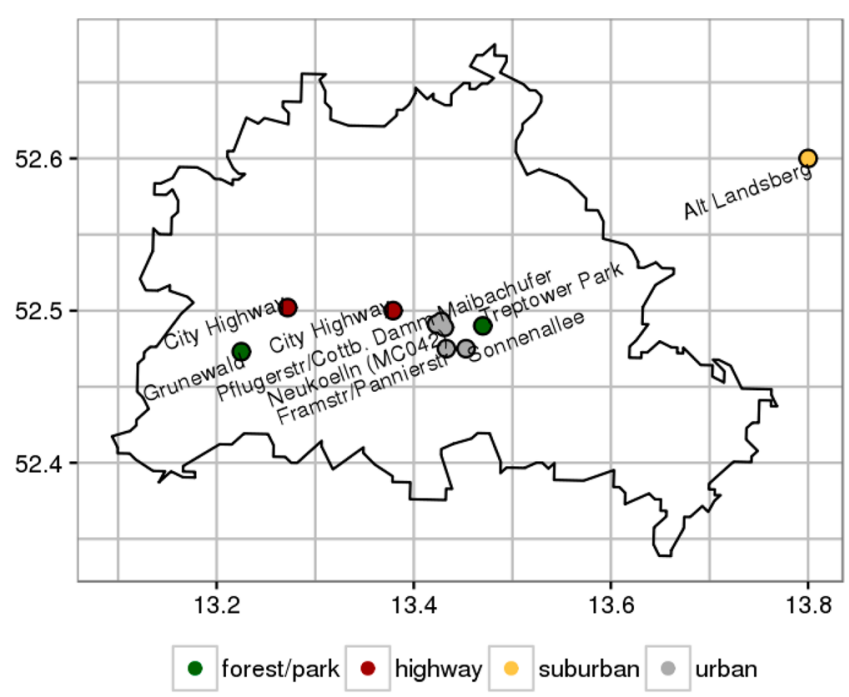

Figure 1. Locations of sites, where canister samples with VOCs have been collected during the BAERLIN field campaign ${ }^{38}$ in summer 2014. The city limits of Berlin are shown with a black line.

addition, air samples have been taken with canisters in different locations of Berlin and one location in Brandenburg (Figure 1, Table 1$)^{38}$ Continuous measurements were performed using a Proton Transfer Reaction-Mass Spectrometry (PTR-MS) system from June sixth until August 29th, 2014 at the Neukölln site (MC042). ${ }^{39} 68$ air constituents were continuously monitored with a $5 \mathrm{~min}$ time step. Collection of canister samples took place at the sites representing urban background, urban forest and park, as well as city's highways. For these samples ambient air was flushed into prevacuumed canisters and diluted by synthetic air. Ozone was removed by a heated steel surface at the inlet line to prevent further oxidation of collected VOCs. The VOCs in these samples were analyzed using a gas chromatography-mass spectrometry instrument. ${ }^{38}$ This allowed detection of individual constituents and quantification of the spatial heterogeneity in VOCs concentrations across Berlin related to changing environmental conditions and VOC emission sources. ${ }^{38}$

Model Setup. In this study, we use the Weather Research and Forecasting model version 3.7.1 coupled online with atmospheric chemistry, ${ }^{40,41}$ as well as with the Model of Emissions of Gases and Aerosols from Nature (MEGAN), version $2.04 .^{42}$ We refer to this model as WRF-Chem in this paper. MEGAN simulates emissions of 20 classes of volatile organic compounds from vegetation including isoprene, monoterpenes (trans- $\beta$-ocimene, 3 -carene, myrcene, limonene, sabinene, $\alpha$-pinene, $\beta$-pinene, and other monoterpenes), and sesquiterpenes ( $\alpha$-farnesene, $\beta$-caryophyllene, and other sesquiterpenes). Anthropogenic emissions of $\mathrm{CO}, \mathrm{NO}_{x}, \mathrm{SO}_{2}$, nonmethane volatile organic compounds (NMVOCs), $\mathrm{PM}_{10}$, and $\mathrm{PM}_{2.5}$, and $\mathrm{NH}_{3}$ were based on TNO-MACC III inventory. We used a modified version of these emissions described in Mar et al. (2016) as an input to model simulations. For 2014 we used emissions from 2011, which was the latest year with anthropogenic emissions available for our model simulations. Although the total annual anthropogenic emissions for Germany slightly decreased (CO (-9\%), $\mathrm{NH}_{3}(-2 \%)$, NMVOC (-11\%), NOX (-18\%), $\mathrm{PM}_{10}$ (-7\%), PM 2.5 $(-9 \%)$, and $\left.\mathrm{SO}_{2}(-8 \%)\right)$ between 2006 and 2011, these emissions are prescribed in the model simulations and thus not sensitive to air temperature.

The model setup includes the Regional Acid Deposition Model mechanism (RADM2) ${ }^{43}$ in the kinetic preprocessor (KPP) version and the MADE/SORGAM aerosol scheme. MADE/SORGAM scheme is based on the Modal Aerosol Dynamics Model for Europe (MADE) $)^{44,45}$ and Secondary Organic Aerosol Model (SORGAM). ${ }^{46}$ Monoterpenes and sesquiterpenes are not represented explicitly in RADM2, but described by the lumped mechanism species "OLI". "OLI" represents all alkenes with an internal double bond, so that a range of VOC species is lumped into this generic chemical mechanism species.

We set up the WRF-Chem model in a one-way nested configuration centered on Berlin with a horizontal resolution of $15 \times 15 \mathrm{~km}^{2}$ for the outermost domain, a $3 \times 3 \mathrm{~km}^{2}$ for the first nested domain, and a $1 \times 1 \mathrm{~km}^{2}$ for the innermost domain. The model domains extend vertically up to $50 \mathrm{hPa}$ and are divided into 35 vertical levels. The lowest level is centered at around 30

Table 1. Description of Sites, Where Canister Samples with VOCs Have Been Collected during the BAERLIN Field Campaign in Summer 2014

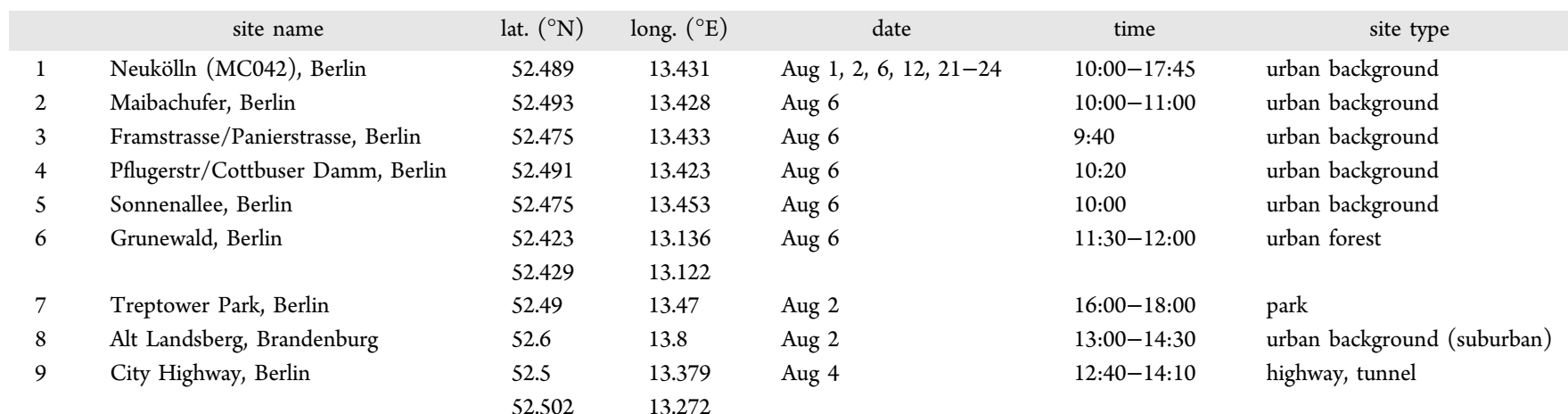

${ }^{a}$ If several coordinates are given, samples have been collected at different locations in the same area. 
Table 2. Fractions of the Four Plant Functional Type Categories (Broadleaf/Needleleaf Trees, Shrubs/Brush, Herbaceous/ Crop) Assigned to Each of the CORINE Urban Land Use Types ${ }^{a}$

\begin{tabular}{|c|c|c|c|c|c|c|c|}
\hline \multicolumn{4}{|c|}{ CORINE } & \multicolumn{4}{|c|}{ MEGAN } \\
\hline land use types & grid ID & vegetated \% & sealed \% & broad leaf tree $\%$ & needle leaf tree $\%$ & shrub/brush \% & herbaceous/crop \% \\
\hline continuous urban fabric & 1 & 20 & 80 & 5 & 5 & 5 & 5 \\
\hline discontinuous urban fabric & 2 & 80 & 20 & 20 & 20 & 20 & 20 \\
\hline industrial or commercial units & 3 & 20 & 80 & 5 & 5 & 5 & 5 \\
\hline road and rail networks and associated land & 4 & 20 & 80 & 5 & 5 & 5 & 5 \\
\hline port areas & 5 & 20 & 80 & 5 & 5 & 5 & 5 \\
\hline airports & 6 & 20 & 80 & 5 & 5 & 5 & 5 \\
\hline dump sites & 8 & 20 & 80 & 5 & 5 & 5 & 5 \\
\hline construction sites & 9 & 20 & 80 & 5 & 5 & 5 & 5 \\
\hline green urban areas & 10 & 80 & 20 & 20 & 20 & 20 & 20 \\
\hline sport and leisure facilities & 11 & 80 & 20 & 20 & 20 & 20 & 20 \\
\hline
\end{tabular}

${ }^{a}$ Mineral extraction sites with Grid ID 7 are excluded because these are not representative for urban areas.

$\mathrm{m}$, and there are 12 vertical levels below $700 \mathrm{hPa}$. We replaced the commonly used land use data from US Geological Survey (USGS) with the land use data from the Coordination of Information on the Environment (CORINE) project for Europe. ${ }^{47} \mathrm{We}$ mapped CORINE land use classes to the USGS land use classes and included three urban classes. We did not use MODIS land cover data available for WRF-Chem, because all urban areas are mapped into a single land use class in this data set.

The model setup with the exact geographical locations of model domains, the physical and chemical parametrizations applied, as well as mapping of CORINE to the USGS land use classes are described in detail in Kuik et al. ${ }^{48}$ Here, we use the model setup referred to as "base run" in Kuik et al. ${ }^{48}$ with the original, unmodified WRF-Chem parametrization of the dry deposition of gaseous species and the input data for MEGAN described below.

Modification of Inputs to MEGAN. MEGAN, which was originally developed as a stand-alone model, ${ }^{42}$ is called in WRFChem before the atmospheric chemistry module. MEGAN requires input data produced by an accompanying preprocessing tool. Input data required include maps of vegetation type, leaf area index (LAI), and VOC emission factors (emission rates per leaf biomass under defined meteorological conditions of radiation and temperature). The vegetation classification in MEGAN includes four vegetation types such as broadleaf trees, needleleaf trees, shrubs/brushes, and herbaceous/crops/ pastures. Global maps of fractions of each vegetation type per pixel are stored in four data files corresponding to each vegetation type. These global maps have been created using data at three different spatial resolutions, such as $\sim 50 \mathrm{~km}$ (AVHRR, MODIS2, G95-P, HYDE, IMAGE, MAPPS), $\sim 8 \mathrm{~km}$ (IBIS), and $\sim 1 \mathrm{~km}$ (SPOT, AVHRR2, MODIS3, MEGANP). ${ }^{42}$ The source of the MEGAN vegetation data differs for various parts of the world. For Europe, it is the "default" which is the University of Maryland GLCF derived from vegetation continuous fields based on AVHRR and MODIS satellite data (http://glcf.umd.edu/data/vcf/) (Alex Guenther, personal communication). These data do not provide information on urban areas and therefore values from the surrounding region were interpolated over these areas for MEGAN vegetation classification.

In the MEGAN input data set, vegetation in Berlin is characterized primarily by grassland and shrublands with a maximum LAI of two. In reality, the dominant vegetation types in Berlin are broadleaf/needleleaf trees mixed with grasses and shrubs. We, therefore, used the CORINE land use data set, ${ }^{47}$ which provides a state-of-the-art land cover classification for Europe, to adjust the MEGAN land cover data sets $(1 \mathrm{~km}$ resolution) for urban areas. The original CORINE data set includes 44 land use classes at spatial resolutions of 250 and 100 m. Pixels identified as "urban" in CORINE (with GRID ID 1-11, Table 2) have been adjusted in the respective input data sets for MEGAN. All other "non-urban" pixels are retained with their original properties, because they represent vegetation surrounding urban areas reasonably well. The adjusted input data sets for MEGAN include fractional vegetation cover (\%) for needle leaf forests, broadleaf forests, shrublands/brushes, herbaceous/crop, as well as the respective LAI. This approach allows a more realistic representation of dominant urban vegetation within each $1 \mathrm{~km}$ pixel of the model domain but cannot represent the heterogeneity of vegetation types and other land use types within those pixels. Representation of the subgrid scale heterogeneity is beyond the scope of this study.

In a first step, the fractional vegetation cover of pixels corresponding to urban land use types in CORINE (Grid ID 111, except mineral extraction sites, Grid ID 7) has been adjusted (Table 2) assuming that land use types such as discontinuous urban fabric, green urban areas, as well as sport and leisure facilities, have a high vegetated fraction (80\%) and low sealed fraction $(20 \%)$. All other urban land use types are assumed to have a high sealed fraction (80\%) and low vegetated fraction (20\%). For consistency, the assumptions about sealed/unsealed fractions are based on the definitions of urban classes suggested for the WRF model by Tewari et al. ${ }^{49}$ and corresponding to the land use classes of CORINE. ${ }^{47}$ Thereafter, the vegetated fraction of each pixel was assumed to be equally covered by four vegetation types represented in MEGAN, for example, urban pixels with $80 \%$ vegetation had $20 \%$ of broadleaf trees, $20 \%$ of needle leaf trees, $20 \%$ of shrub/ brush, and $20 \%$ of herbaceous/crop. A more precise quantification of vegetation fractions and vegetation types in urban areas requires data sets with high spatial resolution, which are not yet available for Europe.

In a second step, the LAI of pixels corresponding to the land use categories $1-11$ in CORINE has been modified: the LAI map of each month has been merged with the fractional vegetation maps. A subset with LAI values for pixels with $20 \%$ of broadleaf/needleleaf trees, $20 \%$ shrub/brush, and $20 \%$ herbaceous/crop have been extracted for each month of the year using the original MEGAN input data sets. Thereafter the maximum, minimum, and mean LAI values for each month 
have been calculated using the values provided in Table S1. The same procedure was used to calculate maximum and minimum LAI values for grid cells with a low vegetated fraction (Table S2). Only LAI values for summer months were used in model simulations in this study.

Model Simulations. To investigate the contribution of biogenic emissions to the formation of ozone and particulate matter during the 2006 heat wave period, simulations with different combinations of anthropogenic and biogenic emissions have been performed (Table 3). Simulations were

Table 3. List of Model Simulations

$\begin{array}{lclll}\begin{array}{c}\text { abbreviation of } \\ \text { model simulation }\end{array} & \begin{array}{c}\text { anthropogenic } \\ \text { emissions }\end{array} & \begin{array}{c}\text { biogenic } \\ \text { emissions }\end{array} & \begin{array}{l}\text { land cover } \\ \text { input data }\end{array} & \text { LAI } \\ \text { ANTH } & \text { included } & \text { none } & & \\ \text { ANTH+BIO } & \text { included } & \text { included } & \text { original } & \text { original } \\ \text { ANTH+BIOm } & \text { included } & \text { included } & \text { modified } & \text { maximum } \\ & & & & \text { minimum }\end{array}$

differentiated into anthropogenic emissions only (ANTH), with both, anthropogenic and biogenic VOC emissions, using original MEGAN input data (ANTH+BIO), and with both, anthropogenic and biogenic VOC emissions, using modified MEGAN input data (ANTH+BIOm). The modified MEGAN input data include changes to the four fractional vegetation types and LAI of urban areas as described in the previous section. Under scenario ANTH+BIOm we performed two model simulations with maximum and minimum LAI in order to reflect the uncertainty connected with the somewhat arbitrary determination of vegetation type fractions. The model simulations have been performed for the time periods June 1-August 28, 2006 and June 1-August 28, 2014.

The Impact of Biogenic VOCs on Air Quality. To estimate the impact of VOCs from plants on ozone (Impact $\left.{ }_{\text {ozone }}\right)$ we calculate the difference in ozone values between model simulations with $\left(\mathrm{OZONE}_{\mathrm{ANTH}+\mathrm{BIO}}\right)$ and without $\left(\mathrm{OZONE}_{\mathrm{ANTH}}\right)$ emissions of biogenic VOCs normalized by the modeled ozone values obtained with anthropogenic VOC emissions only $\left(\mathrm{OZONE}_{\mathrm{ANTH}}\right)$ :

$$
\text { Impact }_{\text {ozone }}=\frac{\mathrm{OZONE}_{\mathrm{ANTH}+\mathrm{BIO}}-\mathrm{OZONE}_{\mathrm{ANTH}}}{\mathrm{OZONE}_{\mathrm{ANTH}}} \times 100
$$

Ozone values $\left(\mathrm{OZONE}_{\mathrm{ANTH}+\mathrm{BIO}}\right.$ and $\left.\mathrm{OZONE}_{\mathrm{ANTH}}\right)$ represent the 8-h daily maximum values, which were calculated as follows. Running 8-h averages were calculated for each hour of the day. The highest 8-h average for each day was then recorded as the 8 -h daily maximum and used to estimate the impact of VOCs from vegetation on ozone. We use the maximum daily 8-h average for ozone because this is the most policy-relevant metric. This metric is used by the World Health Organization (WHO) in their guidelines for the protection of human health and national air quality legislation around the world.

The seasonal mean contributions of biogenic VOCs were calculated as means with standard deviations of the relative impact $\left(\right.$ Impact $\left._{\text {ozone }}\right)$ of six grid model cells over the summers of 2006 and 2014.

To assess the impact of changes in VOCs from vegetation on particulate matter we investigated their effect on the simulated SOA concentration. SOA formation is very closely linked to the biogenic emissions of VOCs and we expected a substantial contribution to SOA during the periods with high VOC emissions from vegetation. SOA anomalies for 2006 were calculated relative to the SOA average over the summer (Figure S4), for example, SOA deviations from the model mean. Because of the poor signal-to-noise ratio in SOA, the effect of changes in biogenic SOA emissions on the total mass concentration of $\mathrm{PM}_{1}$ or $\mathrm{PM}_{2.5}$ is not investigated here.

Model Evaluation. The ability of WRF-Chem with the above-mentioned setup to simulate various meteorological and chemical variables in the Berlin-Brandenburg metropolitan area was evaluated in-depth using observational data for the summer of 2014 by Kuik et al. ${ }^{48}$ Here, we only compare model performances for $2 \mathrm{~m}$ air temperature and ozone between 2014 and 2006.

We also test the model's ability to simulate realistic concentrations of biogenic VOCs and their sensitivity to the prescribed input data, that is, vegetation fraction and type. We extracted the simulated isoprene concentrations from the $1 \times 1$ $\mathrm{km}^{2}$ grid cells of the innermost model domain corresponding to the locations of the observational sites (Table 1). Some measurements were taken relatively close to each other and were within the same model grid cell (Table 1, sites 1-4). These measurements were then averaged and compared to the corresponding simulated values. The remaining five sampling sites (Table 1, sites 5-9) were located in different grid cells of the model and were compared to corresponding simulated concentrations of isoprene. Observed values represent point measurements of isoprene concentrations averaged over $1 \mathrm{~h}$ at the observational sites (Table 1). Simulated and observed isoprene values below $0.05 \mathrm{ppbV}$ were excluded from the analysis of the correlation between observed and modeled isoprene concentrations, because the corresponding observed data are close to or below the detection limit. We compare the simulated response of ozone to biogenic VOCs for grid cells, where measurements of isoprene were available, as explained above.

We compare isoprene emission factors in the MEGAN model to the ones calculated based on the species composition within the vegetation types typical for Berlin. For this we compared isoprene emission factors for grid cells with the highest fractions $(>60 \%)$ of four vegetation types such as deciduous broadleaf forest, evergreen needleleaf forest, shrublands, and herbaceous/croplands. To calculate isoprene emissions factors typical for Berlin vegetation, we used the inventory of Berlin street trees ${ }^{50}$ for deciduous broadleaf forests and data provided by the Umweltatlas of Berlin ${ }^{51}$ for evergreen needleleaf forests. This includes a $31 \%$ fraction of deciduous trees including $13 \%$ oaks. The emission factors were taken from various literature sources (see Tables S3 and S4 for details) and the units were transformed using the foliage density values ${ }^{52}$ and the canopy correction factor. ${ }^{42}$

\section{RESULTS AND DISCUSSION}

Effect of Biogenic VOCs on Air Quality. Results of the model simulations show that the VOCs of biogenic origin contribute substantially ( $\sim 12 \%$ on average) to the ground level ozone formation in Berlin in summer. The mean contributions of biogenic VOCs in the ANTH+BIO simulation increase from $9-11 \%$ in June to $17-20 \%$ in July and drops to $6-9 \%$ in August (Table 4). These fluctuations correspond to respective changes in air temperature and isoprene concentration. The mean contribution of biogenic VOCs to ozone concentrations slightly changed in response to alteration in land cover and LAI $(\mathrm{ANTH}+\mathrm{BIOm})$ with contributions of around $12 \%( \pm 7 \%$ for 
Table 4. Modeled Monthly Means of Temperature, Isoprene, Ozone, and Impact Factors for 2006 and 2014

\begin{tabular}{|c|c|c|c|c|c|c|}
\hline \multirow[b]{2}{*}{ variable } & \multicolumn{2}{|c|}{ June } & \multicolumn{2}{|c|}{ July } & \multicolumn{2}{|c|}{ August } \\
\hline & 2006 & 2014 & 2006 & 2014 & 2006 & 2014 \\
\hline temperature $\left[{ }^{\circ} \mathrm{C}\right]$ & 19 & 18 & 24 & 22 & 19 & 19 \\
\hline $\begin{array}{l}\text { temperature maximum } \\
{\left[{ }^{\circ} \mathrm{C}\right]}\end{array}$ & 23 & 22 & 28 & 26 & 24 & 23 \\
\hline isoprene $[\mathrm{ppbv}]$ & 0.42 & 0.35 & 0.63 & 0.52 & 0.31 & 0.32 \\
\hline $\begin{array}{l}\text { ozone maximum } 8 \mathrm{~h} \\
{\left[\mu \mathrm{g} \mathrm{m}^{-3}\right]}\end{array}$ & 87 & 79 & 91 & 83 & 78 & 76 \\
\hline impact factor [\%] & 11 & 9 & 20 & 17 & 6 & 9 \\
\hline
\end{tabular}

max LAI and $\pm 14 \%$ for min LAI) in 2006 and $\sim 11 \%( \pm 13 \%$ for max LAI and $\pm 12 \%$ for min LAI) in 2014 (Figure S3).

The differences between the modeled ozone responses at various urban sites are small under default conditions (ANTH vs ANTH+BIO). The maximum temporal standard deviation of modeled ozone response to biogenic VOCs at the extracted grid cells with measurements available increased from $\sim 6 \%$ in the ANTH+BIO simulation to $\sim 10 \%$ in the $\mathrm{ANTH}+\mathrm{BIOm}$ simulation in 2006. This is not surprising, because the modified land cover has more patchy vegetation in comparison to the homogeneous vegetation cover of Berlin prescribed in the original MEGAN input data set. The modified land cover has large differences between vegetation fractions in grid cells classified as discontinuous urban fabric, green urban areas, and sport/leisure facilities ( $80 \%$ of area covered with vegetation) and other land use types, for example, continuous urban fabric, roads, etc., with $20 \%$ of area covered with vegetation. In the original land cover data, however, these contrasts between different grid cells within city do not exist.

In the 2006 simulation, the ozone response to VOC emissions from plants reached a maximum of $60 \%$ during the heat wave in July (Figure 2, upper panel). The peak in this response indicates high ozone concentrations resulting from high isoprene concentrations during that period (July 20-30th, Figure 3). The exponential response of isoprene emissions to temperature is well documented ${ }^{10}$ and is reproduced by the model (Figure S2). In the 2014 simulation, the response of the ozone concentrations to biogenic VOC emissions was smaller and did not exceed $42 \%$ reached in June (Figure 2, lower panel). In our model simulations the aerosols were calculated interactively and coupled to the cloud and radiation schemes. The two model simulations used for the calculations of the impact factor have different emissions and therefore somewhat different aerosol fields. These differences result in small differences in the simulated meteorological variables and can thus result in small negative impact factors on days with substantial cloud cover, which is typical for the study area in the beginning and end of summer.

Our results for the heat wave period (Figure 2) are consistent with the observation-based results of Duane et al. ${ }^{53}$ for the North Italian semirural district of Insubria. There, the isoprene emissions from broad-leaf deciduous trees dominated by Populus spp., Quercus spp., and Robinia pseudoacacia were estimated to contribute $50-75 \%$ to local ozone formation in summer. ${ }^{53}$ The reported average daily summer temperatures of that region are $25-30{ }^{\circ} \mathrm{C}$. On the basis of the results of a box model incorporating the Regional Atmospheric Chemistry Mechanism (RACM), Papiez et al. ${ }^{54}$ found that VOC emissions from palm trees (Washingtonia spp.) and ashes (Fraxinus velutina), which have modest basal emission rates, can a)

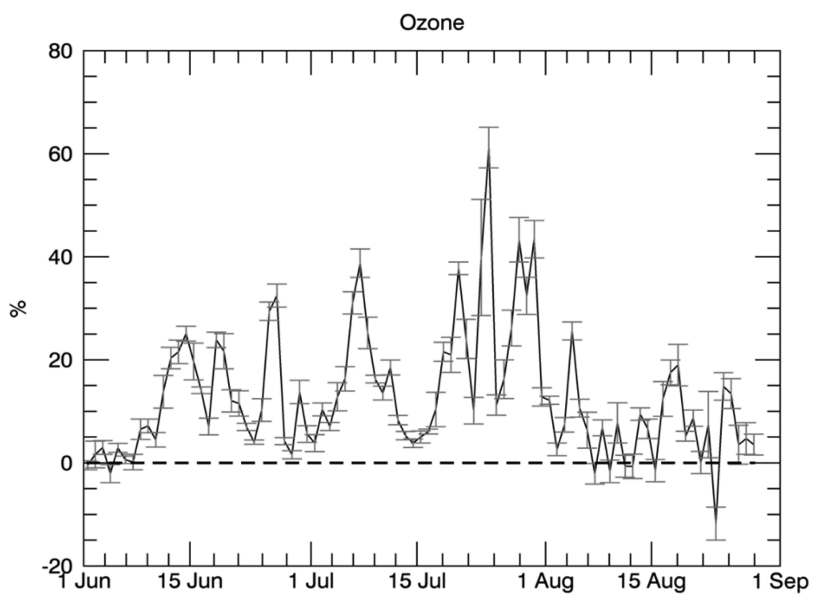

b)

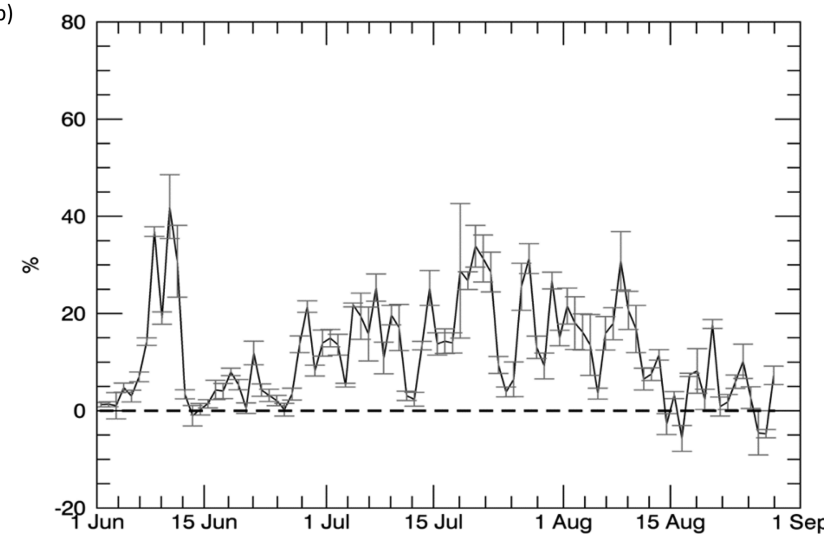

Figure 2. Contribution of VOC emissions from vegetation (eq 1) to the 8-h daily maximum concentrations of ground level ozone in 2006 (upper panel) and 2014 (lower panel) from the ANTH+BIO simulation. The mean impact averaged over six grid cells with measurements is plotted as solid black line. The error bars show the standard deviation of the 8 -h values for each day.

substantially degrade air quality in a suburban location downwind of Las Vegas, U.S. The emissions of biogenic terpenes increased time-dependent ozone production rates by a factor of 50 under conditions of high $\mathrm{NO}_{x}$, low anthropogenic VOC concentrations, and high air temperatures. The mean summer temperatures in Las Vegas are $\sim 38{ }^{\circ} \mathrm{C}$ and higher.

Although our results along with many studies covering Asia, ${ }^{4,55-57}$ Europe, $^{53,58}$ and North America ${ }^{54,59}$ suggest that urban trees may exacerbate air pollution through VOC emissions, other studies of the same phenomenon complicate the picture. Ozone can get captured inside the leaves (e.g., diffusion through leaves' stomata) and on the leaves' surface, as well as other surfaces, such as soils and tree stems. Ozone reacts with NO, as well as VOCs, such as monoterpenes and sesquiterpenes in particular. ${ }^{60-62}$ On the basis of a long time series of observations from Europe and the USA, Paoletti et al. ${ }^{63}$ found that annual average ozone concentrations at both urban and rural sites increased, with a faster rate of increase at urban sites. Traditionally, ozone is lower in urban centers ${ }^{64}$ which is connected to the relation between reaction time and air mass transport as well as the air chemical composition driving photochemistry toward ozone formation due to a more suitable VOC/NOx ratio. ${ }^{65}$ The role of vegetation in this trend is thus the sum of various effects that vary in strength 
2006

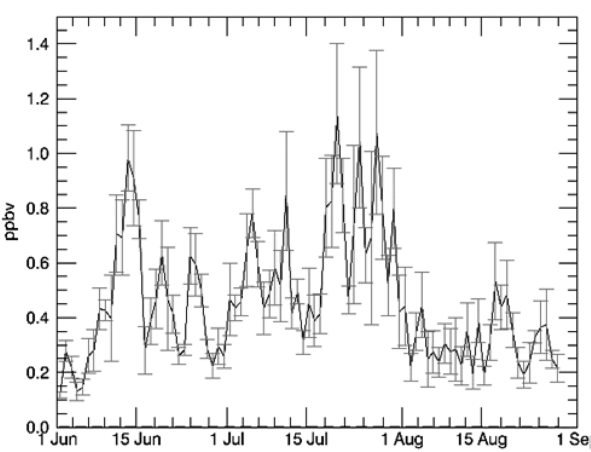

2014

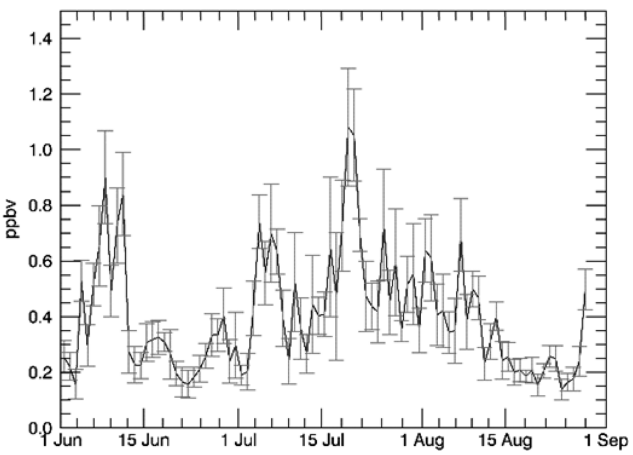

Figure 3. Mean daily maximum concentrations of isoprene in 2006 and 2014 from the ANTH+BIO simulation. The mean averaged over six grid cells is plotted with a solid black line. The error bars show the standard deviation of the 8-h values for each day.

depending on vegetation properties and environmental conditions ${ }^{9}$

We also expected to see a response of the SOA concentration (mass) to the emissions of VOCs from vegetation in the model simulations and an amplification of this response during the heat wave. High temperatures and stable atmospheric conditions during a heat wave can result in an accumulation of SOA in the boundary layer and enhance aging of VOCs (getting less volatile by oxidizing). Indeed, measurements in the Berlin-Brandenburg metropolitan area conducted within the framework of the BAERLIN campaign indicated that VOCs play an important role in particle formation in that area. ${ }^{38}$ Calculated contributions of both anthropogenic and biogenic VOCs to particulate matter formation $\left(\mathrm{PM}_{10}\right)$ in summer 2014 were on average $38.2 \pm 9.4 \%{ }^{39}$ as compared to, for instance, diesel soot contribution of $13.2 \pm 6.2 \%$. $\mathrm{PM}_{10}$ loading was 17.9 $\pm 3.9 \mu \mathrm{g} / \mathrm{m}^{3}$ of which $6.8 \pm 1.9 \%$ was organic carbon. The organic carbon consists of two groups, that is, pre-existing organic carbon that has been transported from elsewhere to the site of interest and organic carbon which is formed onsite. The first group may partially contain aged SOA with a lot of functionalities and lower volatility. In order to separate the organic from elemental carbon, all OC was assumed to be completely volatile at a temperature of $760{ }^{\circ} \mathrm{C}$. If OC was not regained as gas at this temperature it was assumed to be elemental carbon. ${ }^{66}$ The majority of the measured OC was high and medium volatile organic carbon with contributions of $35 \%$ and $43.2 \%$ respectively. On the basis of a box model study (Bonn et al., in prep.), the contribution of anthropogenic VOC sources to SOA formation is small, particularly when away from the emission sources. Close to the highways, however, this contribution is likely to be higher.

Because of the large variability of SOA in the model simulations (Figure S4), statistically significant results for the contribution of biogenic VOC emissions to the simulated particulate matter in the study area could not be obtained. The analysis of the SOA anomalies calculated for several sites in the study area showed a poor signal-to-noise ratio (Figure S4) consequently we did not proceed with the analysis of $\mathrm{PM}_{1}$ and $\mathrm{PM}_{2.5}$. This large variability of the SOA anomalies can be explained by the coupling of the aerosols to cloud formation and radiation in the current model setup and the selected SOA formation mechanism SORGAM, ${ }^{46}$ which is known to systematically underestimate the formation of $\mathrm{SOA}^{67}$ impacting also SOA related aerosol dynamics and deposition. The model deficits can be partially explained by a too simplified treatment of the biogenic VOCs in the RADM2 chemical mechanism of WRF-Chem used here, because eight different groups of monoterpenes and three classes of sesquiterpenes simulated by MEGAN are lumped together into one chemical species (OLI). Individual treatments of the VOC groups implemented in the RADM2 model may alleviate these problems as diverse VOC groups contribute differently to particle formation. Furthermore, RADM2 does not include the oxidation of biogenic monoterpenes and also anthropogenic VOC oxidation is treated in a very simplified manner. ${ }^{68}$

How Reasonable Were the Simulated Responses? Kuik et al. $^{48}$ demonstrated that the WRF-Chem model setup similar to the one in this study simulated meteorological variables reasonably well. Although the modeled diurnal cycle of the planetary boundary layer height was comparable with observations derived from radiosondes and a ceilometer, the height of the nighttime planetary boundary layer was underestimated by the model. Main wind directions were modeled reasonably well. Wind speed was overestimated by $0.5-1.3 \mathrm{~m} / \mathrm{s}$ in the simulation with a $1 \mathrm{~km} \times 1 \mathrm{~km}$ horizontal resolution.

Mean hourly temperatures and daily maximum temperatures at the $2 \mathrm{~m}$ height were simulated well with temporal correlation coefficients of $\sim 0.89-0.93$ (Table S5) and $\sim 0.83-0.92$ (Table S7), respectively, for summers of 2006 and 2014. The 2-m temperature bias was mostly positive and smaller than $+1.5{ }^{\circ} \mathrm{C}$ at all stations with observations available. The model, however, underestimated the highest observed temperatures in both years, for example, during the heat wave of 2006 (Figure S5). Both observations and model indicate that temperatures in 2014 were lower than in 2006 (Table 4 and S6). The temperature difference between the years is slightly higher in the model than in the observations at four out of six observation stations.

The model was able to reproduce maximum daily 8 -h means of the ozone concentration in both 2006 and 2014 with a maximum bias of $-12 \mu \mathrm{g} \mathrm{m}^{-3}$ depending on the station (Table S8).The model, however, slightly underestimated peak ozone concentrations on hot days (Figures S5 and S6) Both observations and model simulations indicated lower ozone concentrations in 2014 than in 2006 at all stations (Table S8 and S9). The differences in ozone concentration between the years at some sites were slightly lower in the model $(1-8 \%)$ than in the observations (8-15\%) (Table S9).

Kuik et al. ${ }^{48}$ found that concentrations of particulate matter were underestimated with large biases. $\mathrm{PM}_{10}$ was under- 
estimated by $\sim 50 \%$, while $\mathrm{PM}_{2.5}$ was underestimated by $\sim 20-$ $35 \%$. An adjustment of the chemical mechanism would be most likely required to simulate values matching the observed concentrations of particulate matter. $\mathrm{NO}_{x}$ concentrations were simulated in good agreement with the observations on average, but overestimated at night, which is probably related to an underestimated boundary layer height.

Observations of Isoprene. Measurements of isoprene mixing ratios obtained during the BAERLIN campaign in 2014 show a gradient from high values in urban forests and parks to low values at urban background stations and very low or close to zero concentrations at city highways (Figure 4). The

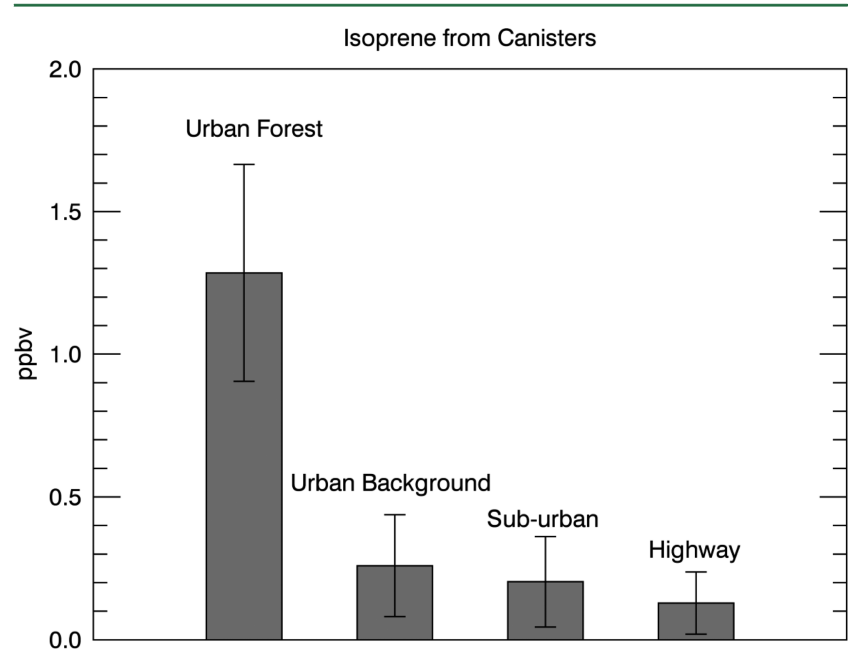

Figure 4. Variability of observed isoprene concentrations over different urban land use types. The bar height indicates the mean hourly concentration calculated from all samples collected at each land use type. The standard deviations are shown as error bars.

differences between urban and suburban sites could be explained by different vegetation fractions. Low values of isoprene mixing ratios observed at city highways could be related to relatively long distance to the emission sources, that is, VOC emitting plants, and/or to available isoprene immediately reacting with $\mathrm{NO}_{x}$ emitted in substantial amounts from motorized vehicles on the highway. The large number of deciduous trees with high emissions of isoprene in urban forest sites is the most likely reason for the high mixing ratios of isoprene characteristic for urban forest.

Although simulated isoprene values at the urban background sites agree reasonably well (gray and black filled circles in Figure 5), the gradient in isoprene concentration from low values near the highway to the high values in urban forests could not be reproduced by the model. In particular, the model overestimates isoprene concentrations at the suburban site and does not capture the high isoprene concentrations characteristic for locations with a high fraction of vegetation (green filled circles in Figure 5) with a model bias in the order of 1-1.4 $\mathrm{ppb}_{\mathrm{v}}$. The underestimation can be attributed to several reasons including spatial resolution (high dilution), emission factors for biogenic VOCs used in the model, poor representation of urban vegetation in the MEGAN input data, as well as the simple chemical mechanism of WRF-Chem used in this study (too fast degradation). In this study we tested how a more refined representation of the vegetation in MEGAN can improve simulations of isoprene.

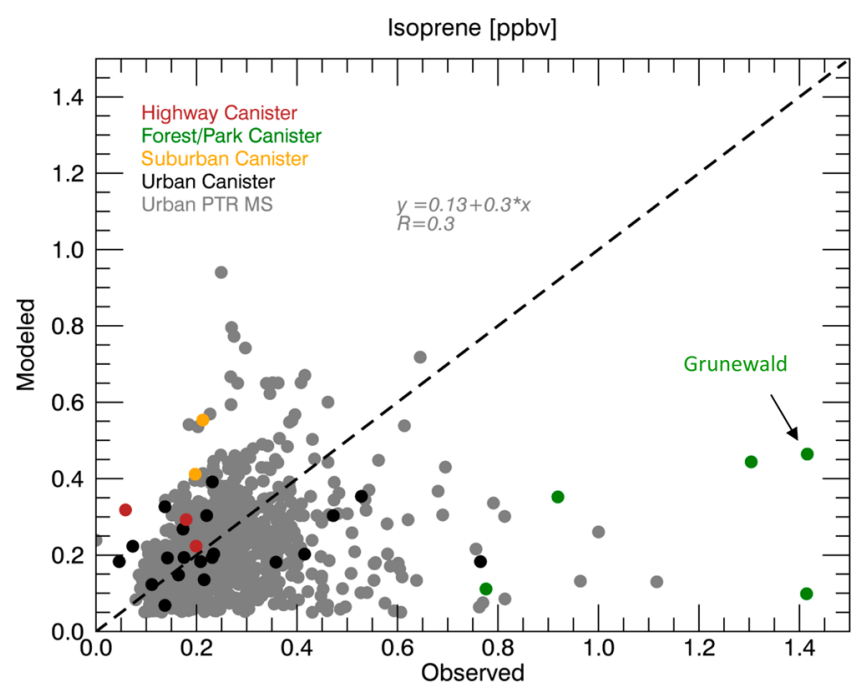

Figure 5. Comparison of modeled and observed concentrations of isoprene measured with PTR-MS and canisters (Table 1) in Berlin in summer 2014. Modeled values represent instantaneous hourly isoprene concentrations calculated for the $1 \times 1 \mathrm{~km}^{2}$ grid cells closest to the measurement sites. Observed values represent point measurement of the isoprene volume mixing ratio averaged over $1 \mathrm{~h}$. Modeled and observed values below $0.05 \mathrm{ppbV}$ have been excluded from this comparison, because such concentrations are below or close to the detection limit of the PTR-MS.

Modification of fractional vegetation types and LAI improves only marginally the isoprene concentrations at the study sites (Figure S7). The improvement was noticeable for a suburban site in Alt Landsberg, where the model originally overestimated concentrations of isoprene (yellow filled circles in Figures 5 and S6) and the urban forest site in Grunewald (green filled circles in Figures 5 and S7), where isoprene values were greatly underestimated in the model simulation with the default MEGAN input data (ANTH+BIO). The modifications of the MEGAN input data resulted in a lower LAI (from 2.9 to 2.1/ 1.7 in July) in Alt Landsberg, which lowered simulated emissions of isoprene at that site, and in higher LAI (from 2.5 to $5.4 / 1.5$ in July) in Grunewald, which increased modeled isoprene values at that site. While for Alt Landsberg this modification resulted in good agreement between modeled and measured isoprene concentration, for Grunewald and other densely vegetated sites the model still underestimates the isoprene by $\sim 0.6-1.4 \mathrm{ppb}_{\mathrm{v}}$ (max LAI simulation). This suggests that also the emission factors of biogenic VOCs would have to be adjusted for urban vegetation, or the LAI would need to be further refined, for example, based on high resolution remote sensing data products.

The isoprene emission factors used in the model likely result in an underestimation of isoprene emissions from vegetation over Berlin, which possibly leads to a correspondingly smaller concentrations of isoprene over green areas (Figure 5) and the ground level ozone, ${ }^{48}$ especially during ozone peaks. To investigate this further, we calculated the emission factors for the Berlin vegetation, considering the species distribution within the different urban green types (Tables 5 and S3). This shows that emission factors used in the model are too low for broadleaved forest. In Berlin, high isoprene emitting species such as oaks, plane trees, and locusts constitute almost $20 \%$ of broadleaf trees. The typical coniferous forests in Berlin are dominated by the low isoprene emitting pines, which may be, 
Table 5. Comparison of Isoprene Emission Factors Used in MEGAN and Calculated from Literature Values for Berlin Vegetation $^{a}$

$\begin{array}{cccc}\begin{array}{c}\text { modeled } \\ \text { vegetation } \\ \text { types }\end{array} & \begin{array}{c}\text { maximum } \\ \text { pixel area } \\ \text { covered in } \\ \text { MEGAN [\%] }\end{array} & \begin{array}{c}\text { emission factors } \\ \text { assumed in } \\ \text { MEGAN } \\ {\left[\mathrm{mol} \mathrm{km}^{-2} \mathrm{~h}^{-1}\right]}\end{array} & \begin{array}{c}\text { emission factors from } \\ \text { literature weighted by } \\ \text { species composition } \\ {\left[\mathrm{mol} \mathrm{km}^{-2} \mathrm{~h}^{-1}\right]}\end{array} \\ \begin{array}{c}\text { deciduous } \\ \text { broadleaf } \\ \text { forest }\end{array} & 64 & 78-84 & 102 \\ \begin{array}{c}\text { evergreen } \\ \text { needleleaf } \\ \text { forest }\end{array} & 76 & 8-37 & 26 \\ \text { shrublands } & 73 & 76-91 & 84 \\ \text { herbaceous } & 95 & 6-54 & 15\end{array}$

${ }^{a}$ Emission factors were extracted for grid cells with maximum vegetation coverage $(>60 \%)$ in the study area (innermost domain of the model simulations).

however, compensated by an addition of $13 \%$ of oaks. Since these are not evenly distributed, local emission factors of conifer forests might be higher than the calculated average.

The model simulations suggest that vegetation has a pronounced effect on the ground level of ozone in Berlin, Germany. The mean contribution of biogenic VOCs to the ozone in Berlin is the highest in July (17-20\%), which is the warmest month in that area. In June and August it is considerably lower $(6-11 \%)$. The contribution reaches its maximum $(\sim 60 \%)$ during the heat wave in July 2006 and during hot summer days in $2014(\sim 40 \%)$ because vegetation emits more VOCs with rising temperatures. This modeled contribution is likely to be on a low side as WRF-Chem underestimates biogenic VOC concentrations from vegetated urban areas. Observations of VOCs suggest that isoprene mixing ratios could reach $1.4 \mathrm{ppb}_{v}$, while corresponding modeled values are $0.05-0.8 \mathrm{ppb}_{\mathrm{v}}$ over urban broadleaf forests and parks of Berlin. These green areas may become potential hot spots for ozone in summer. Previous studies showed that $\mathrm{NO}_{x}$ concentrations in Berlin remained high over the years and were thought to be responsible for elevated ozone levels in the presence of sufficient VOCs. Reducing car traffic in the city, which is the major source of $\mathrm{NO}_{x}$ and of anthropogenic VOCs, remains a top priority here.

Our modeling study revealed shortcomings of WRF-Chem for simulations over urban areas. First, WRF-Chem as set up in this study has a limited ability to simulate SOA, PM, and associated effects of biogenic VOCs on PM formation in urban areas. Refined treatment of biogenic VOCs and an improved representation of SOA in WRF-Chem are needed to assess the effects of biogenic VOCs on particle formation in urban areas. Explicit representation of monoterpenes and sesquiterpenes in the chemical mechanisms of WRF-Chem would be recommended. Second, WRF-Chem has a limited ability to simulate isoprene mixing ratios over urban forests because of a rather poor representation of urban vegetation in MEGAN (location, leaf area index, VOC emission factors). It should be kept in mind that an evaluation of modeled isoprene concentrations with point measurements is challenging because of the rather coarse spatial model resolution $(1 \times 1 \mathrm{~km})$.

The heat wave in 2006 resulted in an increased premature mortality in Berlin, which was primarily attributed to high air temperatures. ${ }^{34}$ The increased air pollution during that heat wave may have contributed to the amplified premature mortality as well. Previous studies report enhanced levels of ozone and particulate matter also indoors, where people spend most of their time and consequently breath in a higher than usual amount of air pollutants during the heat wave in Europe in summer $2003 .{ }^{69}$ Implications of high temperature combined with high air pollution concentrations for human mortality are still not that clear. Air pollutants may have confounding and/or synergistic effects on the temperature-mortality relation. ${ }^{70}$ Our study demonstrates that biogenic VOCs can contribute considerably to enhanced air pollution during heat waves. Therefore, we emphasize the dual role of vegetation for air quality and human health in cities during warm seasons, which is removal (through leaf stomata uptake and plant surface deposition) and lessening (through reduction of heat island effect) versus enhancement of air pollution. Radical reduction of anthropogenic sources of $\mathrm{NO}_{x}$, VOCs, and PM through city traffic reduction would have to accompany urban tree planting campaigns in order to make them fully beneficial for urban dwellers.

\section{ASSOCIATED CONTENT}

\section{S Supporting Information}

The Supporting Information is available free of charge on the ACS Publications website at DOI: 10.1021/acs.est.6b06514.

Detailed description of LAI modifications, detailed description of the VOC emission factor conversion, VOC emissions of trees and shrubs at Nansen Str., simulated responses of isoprene concentrations to temperature, contribution of VOC emissions from vegetation to the 8 -h daily maximum concentrations of ground level ozone with minimum and maximum LAI for the ANTH+BIOm simulations, SOA anomalies in summer 2006, model performance for $2 \mathrm{~m}$ temperatures and ozone for 2006 and 2014, comparison of modeled and observed concentrations of isoprene in summer 2014 for $\mathrm{ANTH}+\mathrm{BIOm}$ simulations (PDF)

\section{AUTHOR INFORMATION}

\section{Corresponding Author}

*Phone: +49 (030)2093-6809. E-mail: galina@churkina.org. ORCID

Galina Churkina: 0000-0002-5895-7425

Notes

The authors declare no competing financial interest.

\section{ACKNOWLEDGMENTS}

We are grateful to Aurelia Lupascu, anonymous WRF-Helpers, Jörn Quedenau, and Ciaron Linstead for their assistance with model code compilation and model simulations. We thank Jane Coates and Renate Forkel for discussions about the interpretation of models results. G.C., B.B., and R.G. initiated this project during their term as fellows at IASS. G.C. and R.G. also acknowledge funding from the EU COST Action "GreenInUrbs" (FP1204), which facilitated exchange of knowledge and ideas between scientists working on urban green infrastructures in Europe. The model simulations were performed on a high performance cluster, which is an IBM/ Lenovo NeXtScale based system, operated by the Potsdam Institute for Climate Impact Research (PIK) in Germany.

\section{REFERENCES}

(1) Young, R. F. Planting the Living City. Journal of the American Planning Association 2011, 77 (4), 368-381. 
(2) Knuth, L. Greening Cities for Improving Urban Livelihoods: Legal, Policy and Institutional Aspects of Urban and Peri-Urban Forestry in West and Central Asia (with a Case Study of Armenia), FOWECA/TP/8; FAO: Rome, Italy, 2006; p 75.

(3) Bowler, D. E.; Buyung-Ali, L.; Knight, T. M.; Pullin, A. S. Urban greening to cool towns and cities: A systematic review of the empirical evidence. Landscape Urban Plann. 2010, 97 (3), 147-155.

(4) Wang, X.; Shen, Z.; Cao, J.; Zhang, L.; Liu, L.; Li, J.; Liu, S.; Sun, $\mathrm{Y}$. Characteristics of surface ozone at an urban site of Xi'an in Northwest China. J. Environ. Monit. 2012, 14 (1), 116-126.

(5) Zhao, H.; Chen, X.; Hao, S.; Jiang, Y.; Zhao, J.; Zou, C.; Xie, W. Is the wash-off process of road-deposited sediment source limited or transport limited? Sci. Total Environ. 2016, 563-564, 62-70.

(6) Li, Z.; Liang, Y.; Zhou, J.; Sun, X. Impacts of de-icing salt pollution on urban road greenspace: a case study of Beijing. Front. Environ. Sci. Eng. 2014, 8 (5), 747-756.

(7) Calfapietra, C.; Peñuelas, J.; Niinemets, T. Urban plant physiology: Adaptation-mitigation strategies under permanent stress. Trends Plant Sci. 2015, 20 (2), 72-75.

(8) Churkina, G.; Grote, R.; Butler, T. M.; Lawrence, M. Natural selection? Picking the right trees for urban greening. Environ. Sci. Policy 2015, 47 (0), 12-17.

(9) Calfapietra, C.; Fares, S.; Manes, F.; Morani, A.; Sgrigna, G.; Loreto, F. Role of Biogenic Volatile Organic Compounds (BVOC) emitted by urban trees on ozone concentration in cities: A review. Environ. Pollut. 2013, 183, 71-80.

(10) Guenther, A. B.; Zimmerman, P. R.; Harley, P. C.; Monson, R K.; Fall, R. Isoprene and monoterpene emission rate variability: Model evaluations and sensitivity analyses. J. Geophys. Res. 1993, 98 (D7), 12609-12617.

(11) Xu, S.; Chen, W.; Huang, Y.; He, X. Responses of Growth, Photosynthesis and VOC Emissions of Pinus tabulaeformis Carr. Exposure to Elevated CO2 and/or Elevated O3 in an Urban Area. Bull. Environ. Contam. Toxicol. 2012, 88 (3), 443-448.

(12) Niinemets, Ü.; Kännaste, A.; Copolovici, L. Quantitative patterns between plant volatile emissions induced by biotic stresses and the degree of damage. Front. Plant Sci. 2013, 4, 262.

(13) Brilli, F.; Hörtnagl, L.; Bamberger, I.; Schnitzhofer, R.; Ruuskanen, T. M.; Hansel, A.; Loreto, F.; Wohlfahrt, G. Qualitative and Quantitative Characterization of Volatile Organic Compound Emissions from Cut Grass. Environ. Sci. Technol. 2012, 46 (7), 38593865.

(14) Possell, M.; Hewitt, C. N. Isoprene emissions from plants are mediated by atmospheric $\mathrm{CO} 2$ concentrations. Global Change Biol. 2011, 17 (4), 1595-1610.

(15) Seinfeld, J. H.; Pandis, S. N. Atmospheric Chemistry and Physics: From Air Pollution to Climate Change; Wiley, 2006.

(16) Park, J.-H.; Goldstein, A. H.; Timkovsky, J.; Fares, S.; Weber, R.; Karlik, J.; Holzinger, R. Active Atmosphere-Ecosystem Exchange of the Vast Majority of Detected Volatile Organic Compounds. Science 2013, 341 (6146), 643-647.

(17) Chameides, W.; Lindsay, R.; Richardson, J.; Kiang, C. The role of biogenic hydrocarbons in urban photochemical smog: Atlanta as a case study. Science 1988, 241 (4872), 1473-1475.

(18) Hoffmann, T.; Odum, J.; Bowman, F.; Collins, D.; Klockow, D.; Flagan, R.; Seinfeld, J. Formation of Organic Aerosols from the Oxidation of Biogenic Hydrocarbons. J. Atmos. Chem. 1997, 26 (2), $189-222$.

(19) Zhang, Q.; Jimenez, J. L.; Canagaratna, M. R.; Allan, J. D.; Coe, H.; Ulbrich, I.; Alfarra, M. R.; Takami, A.; Middlebrook, A. M.; Sun, Y. L.; Dzepina, K.; Dunlea, E.; Docherty, K.; DeCarlo, P. F.; Salcedo, D.; Onasch, T.; Jayne, J. T.; Miyoshi, T.; Shimono, A.; Hatakeyama, S.; Takegawa, N.; Kondo, Y.; Schneider, J.; Drewnick, F.; Borrmann, S.; Weimer, S.; Demerjian, K.; Williams, P.; Bower, K.; Bahreini, R.; Cottrell, L.; Griffin, R. J.; Rautiainen, J.; Sun, J. Y.; Zhang, Y. M.; Worsnop, D. R. Ubiquity and dominance of oxygenated species in organic aerosols in anthropogenically-influenced Northern Hemisphere midlatitudes. Geophys. Res. Lett. 2007, 34, L13801.
(20) Fuzzi, S.; Baltensperger, U.; Carslaw, K.; Decesari, S.; Denier van der Gon, H.; Facchini, M. C.; Fowler, D.; Koren, I.; Langford, B.; Lohmann, U.; Nemitz, E.; Pandis, S.; Riipinen, I.; Rudich, Y.; Schaap, M.; Slowik, J. G.; Spracklen, D. V.; Vignati, E.; Wild, M.; Williams, M.; Gilardoni, S. Particulate matter, air quality and climate: lessons learned and future needs. Atmos. Chem. Phys. 2015, 15 (14), 8217-8299.

(21) Tunved, P.; Hansson, H.-C.; Kerminen, V.-M.; Ström, J.; Maso, M. D.; Lihavainen, H.; Viisanen, Y.; Aalto, P. P.; Komppula, M.; Kulmala, M. High Natural Aerosol Loading over Boreal Forests. Science 2006, 312 (5771), 261-263.

(22) Tunved, P.; Ström, J.; Kulmala, M.; Kerminen, V. M.; Dal Maso, M.; Svenningson, B.; Lunder, C.; Hansson, H. C. The natural aerosol over Northern Europe and its relation to anthropogenic emissionsimplications of important climate feedbacks. Tellus, Ser. B 2008, 60 (4), 473-484.

(23) Ghirardo, A.; Xie, J.; Zheng, X.; Wang, Y.; Grote, R.; Block, K.; Wildt, J.; Mentel, T.; Kiendler-Scharr, A.; Hallquist, M.; ButterbachBahl, K.; Schnitzler, J. P. Urban stress-induced biogenic VOC emissions and SOA-forming potentials in Beijing. Atmos. Chem. Phys. 2016, 16 (5), 2901-2920.

(24) Paasonen, P.; Asmi, A.; Petaja, T.; Kajos, M. K.; Aijala, M.; Junninen, H.; Holst, T.; Abbatt, J. P. D.; Arneth, A.; Birmili, W.; van der Gon, H. D.; Hamed, A.; Hoffer, A.; Laakso, L.; Laaksonen, A.; Richard Leaitch, W.; Plass-Dulmer, C.; Pryor, S. C.; Raisanen, P.; Swietlicki, E.; Wiedensohler, A.; Worsnop, D. R.; Kerminen, V.-M.; Kulmala, M. Warming-induced increase in aerosol number concentration likely to moderate climate change. Nat. Geosci. 2013, 6 (6), $438-442$.

(25) Megaritis, A. G.; Fountoukis, C.; Charalampidis, P. E.; Pilinis, C.; Pandis, S. N. Response of fine particulate matter concentrations to changes of emissions and temperature in Europe. Atmos. Chem. Phys. 2013, 13 (6), 3423-3443.

(26) Goldstein, A. H.; Galbally, I. E. Known and Unexplored Organic Constituents in the Earth's Atmosphere. Environ. Sci. Technol. 2007, 41 (5), 1514-1521.

(27) Coates, J.; Mar, K. A.; Ojha, N.; Butler, T. M. The influence of temperature on ozone production under varying NOx conditions - a modelling study. Atmos. Chem. Phys. 2016, 16 (18), 11601-11615.

(28) Zhao, L.; Lee, X.; Smith, R. B.; Oleson, K. Strong contributions of local background climate to urban heat islands. Nature 2014, 511 (7508), 216-219.

(29) Grimmond, S. U. E. Urbanization and global environmental change: local effects of urban warming. Geogr. J. 2007, 173 (1), 83-88.

(30) Li, D.; Bou-Zeid, E. Synergistic Interactions between Urban Heat Islands and Heat Waves: the Impact in Cities is Larger than the Sum of its Parts. Journal of Applied Meteorology and Climatology 2013, 52, 2051.

(31) Vautard, R.; Honoré, C.; Beekmann, M.; Rouil, L. Simulation of ozone during the August 2003 heat wave and emission control scenarios. Atmos. Environ. 2005, 39 (16), 2957-2967.

(32) Stedman, J. R. The predicted number of air pollution related deaths in the UK during the August 2003 heatwave. Atmos. Environ. 2004, 38 (8), 1087-1090.

(33) Lee, J. D.; Lewis, A. C.; Monks, P. S.; Jacob, M.; Hamilton, J. F.; Hopkins, J. R.; Watson, N. M.; Saxton, J. E.; Ennis, C.; Carpenter, L. J.; Carslaw, N.; Fleming, Z.; Bandy, B. J.; Oram, D. E.; Penkett, S. A.; Slemr, J.; Norton, E.; Rickard, A. R.; K Whalley, L.; Heard, D. E.; Bloss, W. J.; Gravestock, T.; Smith, S. C.; Stanton, J.; Pilling, M. J.; Jenkin, $\mathrm{M}$. E. Ozone photochemistry and elevated isoprene during the UK heatwave of august 2003. Atmos. Environ. 2006, 40 (39), 75987613.

(34) Gabriel, K. M. A.; Endlicher, W. R. Urban and rural mortality rates during heat waves in Berlin and Brandenburg, Germany. Environ. Pollut. 2011, 159 (8-9), 2044-2050.

(35) Amt für Statistik Berlin-Brandenburg Statistik Berlin Brandenburg. https://www.statistik-berlin-brandenburg.de/statistiken/inhaltstatistiken.asp (accessed March 2016).

(36) Senatsverwaltung für Stadtentwicklung und Umwelt Berlin Bericht Nr. 13; Berlin, 31.12.2013, 2015. 
(37) DWD ftp://ftp-cdc.dwd.de/pub/CDC/observations germany/ climate/multi_annual/mean_81-10/ (accessed May, 2016).

(38) Bonn, $\bar{B}_{\text {.; }}$ von Schneidemesser, E.; Andrich, D.; Quedenau, J.; Gerwig, H.; Lüdecke, A.; Kura, J.; Pietsch, A.; Ehlers, C.; Klemp, D.; Kofahl, C.; Nothard, R.; Kerschbaumer, A.; Junkermann, W.; Grote, R.; Pohl, T.; Weber, K.; Lode, B.; Schönberger, P.; Churkina, G.; Butler, T. M.; Lawrence, M. G. BAERLIN2014 - The influence of land surface types on and the horizontal heterogeneity of air pollutant levels in Berlin. Atmos. Chem. Phys. 2016, 16 (12), 7785-7811.

(39) von Schneidemesser, E.; Bonn, B.; Ehlers, C.; Gerwig, H.; Hellén, H.; Kerschbaumer, A.; Klemp, D.; Kofahl, C.; Kura, J.; Lüdecke, A.; Nothard, R.; Pietsch, A.; Pohl, T.; Schaefer, K.; Weber, K. BÄRLIN2014-stationary measurements and source apportionment at an urban background station in Berlin, Germany, Atmospheric Chemistry and Physics, to be submitted.

(40) Grell, G. A.; Peckham, S. E.; Schmitz, R.; McKeen, S. A.; Frost, G.; Skamarock, W. C.; Eder, B. Fully coupled "online" chemistry within the WRF model. Atmos. Environ. 2005, 39 (37), 6957-6975.

(41) Fast, J. D.; Gustafson, W. I.; Easter, R. C.; Zaveri, R. A.; Barnard, J. C.; Chapman, E. G.; Grell, G. A.; Peckham, S. E. Evolution of ozone, particulates, and aerosol direct radiative forcing in the vicinity of Houston using a fully coupled meteorology-chemistry-aerosol model. J. Geophys. Res. 2006, 111 (D21), D21305.

(42) Guenther, A.; Karl, T.; Harley, P.; Wiedinmyer, C.; Palmer, P. I.; Geron, C. Estimates of global terrestrial isoprene emissions using MEGAN (Model of Emissions of Gases and Aerosols from Nature). Atmos. Chem. Phys. 2006, 6 (11), 3181-3210.

(43) Stockwell, W. R.; Middleton, P.; Chang, J. S.; Tang, X. The second generation regional acid deposition model chemical mechanism for regional air quality modeling. J. Geophys. Res. 1990, 95 (D10), 16343-16367.

(44) Binkowski, F. S.; Shankar, U. The Regional Particulate Matter Model: 1. Model description and preliminary results. J. Geophys. Res. 1995, 100 (D12), 26191-26209.

(45) Ackermann, I. J.; Hass, H.; Memmesheimer, M.; Ebel, A.; Binkowski, F. S.; Shankar, U. Modal aerosol dynamics model for Europe: development and first applications. Atmos. Environ. 1998, 32 (17), 2981-2999.

(46) Schell, B.; Ackermann, I. J.; Hass, H.; Binkowski, F. S.; Ebel, A. Modeling the formation of secondary organic aerosol within a comprehensive air quality model system. Journal of Geophysical Research: Atmospheres 2001, 106 (D22), 28275-28293.

(47) EEA Corine Land Cover 2006 raster data. http://www.eea. europa.eu/data-and-maps/data/corine-land-cover-2006-raster-2 (accessed June 2015).

(48) Kuik, F.; Lauer, A.; Churkina, G.; Denier van der Gon, H. A. C.; Fenner, D.; Mar, K. A.; Butler, T. M. Air quality modelling in the Berlin-Brandenburg region using WRF-Chem v3.7.1: sensitivity to resolution of model grid and input data. Geosci. Model Dev. 2016, 9 (12), 4339-4363.

(49) Tewari, M.; Chen, F.; Kusaka, H.; Miao, S. Coupled WRF/ Unified Noah/Urban-Canopy Modeling System; NCAR RAL, 2007; p 22.

(50) Senat, B. Street Tree Inventory. http://www.stadtentwicklung. berlin.de/umwelt/stadtgruen/stadtbaeume/de/daten_fakten/ downloads/ausw_139.pdf (accessed January 2017).

(51) Berlin Senat Umweltatlas Berlin. http://www. 1stadtentwicklung.berlin.de/umwelt/umweltatlas/index.shtml (accessed August 2010).

(52) Guenther, A.; Hewitt, C. N.; Erickson, D.; Fall, R.; Geron, C.; Graedel, T.; Harley, P.; Klinger, L.; Lerdau, M.; McKay, W. A.; Pierce, T.; Scholes, B.; Steinbrecher, R.; Tallamraju, R.; Taylor, J.; Zimmerman, P. A global model of natural volatile organic compound emissions. J. Geophys. Res. 1995, 100 (D5), 8873-8892.

(53) Duane, M.; Poma, B.; Rembges, D.; Astorga, C.; Larsen, B. R. Isoprene and its degradation products as strong ozone precursors in Insubria, Northern Italy. Atmos. Environ. 2002, 36 (24), 3867-3879.

(54) Papiez, M. R.; Potosnak, M. J.; Goliff, W. S.; Guenther, A. B.; Matsunaga, S. N.; Stockwell, W. R. The impacts of reactive terpene emissions from plants on air quality in Las Vegas, Nevada. Atmos. Environ. 2009, 43 (27), 4109-4123.

(55) Kim, S.-Y.; Jiang, X.; Lee, M.; Turnipseed, A.; Guenther, A.; Kim, J.-C.; Lee, S.-J.; Kim, S. Impact of biogenic volatile organic compounds on ozone production at the Taehwa Research Forest near Seoul, South Korea. Atmos. Environ. 2013, 70 (0), 447-453.

(56) Situ, S.; Guenther, A.; Wang, X.; Jiang, X.; Turnipseed, A.; Wu, Z.; Bai, J.; Wang, X. Impacts of seasonal and regional variability in biogenic VOC emissions on surface ozone in the Pearl River delta region, China. Atmos. Chem. Phys. 2013, 13 (23), 11803-11817.

(57) Wang, J.-L.; Chew, C.; Chang, C.-Y.; Liao, W.-C.; Lung, S.-C. C.; Chen, W.-N.; Lee, P.-J.; Lin, P.-H.; Chang, C.-C. Biogenic isoprene in subtropical urban settings and implications for air quality. Atmos. Environ. 2013, 79 (0), 369-379.

(58) Hellén, H.; Tykkä, T.; Hakola, H. Importance of monoterpenes and isoprene in urban air in northern Europe. Atmos. Environ. 2012, $59,59-66$.

(59) Diem, J. E. Comparisons of weekday-weekend ozone: importance of biogenic volatile organic compound emissions in the semi-arid southwest USA. Atmos. Environ. 2000, 34 (20), 3445-3451.

(60) Fares, S.; McKay, M.; Holzinger, R.; Goldstein, A. H. Ozone fluxes in a Pinus ponderosa ecosystem are dominated by non-stomatal processes: Evidence from long-term continuous measurements. Agricultural and Forest Meteorology 2010, 150 (3), 420-431.

(61) Fares, S.; Weber, R.; Park, J. H.; Gentner, D.; Karlik, J.; Goldstein, A. H. Ozone deposition to an orange orchard: Partitioning between stomatal and non-stomatal sinks. Environ. Pollut. 2012, 169, $258-266$.

(62) Gerosa, G.; Vitale, M.; Finco, A.; Manes, F.; Denti, A. B.; Cieslik, S. Ozone uptake by an evergreen Mediterranean Forest (Quercus ilex) in Italy. Part I: Micrometeorological flux measurements and flux partitioning. Atmos. Environ. 2005, 39 (18), 3255-3266.

(63) Paoletti, E.; De Marco, A.; Beddows, D. C. S.; Harrison, R. M.; Manning, W. J. Ozone levels in European and USA cities are increasing more than at rural sites, while peak values are decreasing. Environ. Pollut. 2014, 192, 295-299.

(64) Sartelet, K. N.; Couvidat, F.; Seigneur, C.; Roustan, Y. Impact of biogenic emissions on air quality over Europe and North America. Atmos. Environ. 2012, 53, 131-141.

(65) Sillman, S.; He, D. Some theoretical results concerning O3NOx-VOC chemistry and NOx-VOC indicators. J. Geophys. Res. 2002, 107 (D22), 4659.

(66) Kofahl, C. Hochempfindliche Bestimmung der Organischen und Anorganischen Kohlenstoff-Fraktion in Feinstaubproben Mittels CRDSpektroskopie; University of Applied Sciences Aachen, Jüluch, 2012; p 60.

(67) Tuccella, P.; Curci, G.; Visconti, G.; Bessagnet, B.; Menut, L.; Park, R. J. Modeling of gas and aerosol with WRF/Chem over Europe: Evaluation and sensitivity study. Journal of Geophysical Research: Atmospheres 2012, 117 (D3), D03303.

(68) McKeen, S.; Chung, S. H.; Wilczak, J.; Grell, G.; Djalalova, I.; Peckham, S.; Gong, W.; Bouchet, V.; Moffet, R.; Tang, Y.; Carmichael, G. R.; Mathur, R.; Yu, S. Evaluation of several PM2.5 forecast models using data collected during the ICARTT/NEAQS 2004 field study. J. Geophys. Res. 2007, 112 (D10), D10S20.

(69) Carslaw, N.; Ashmore, M.; Terry, A. C.; Carslaw, D. C. Crucial Role for Outdoor Chemistry in Ultrafine Particle Formation in Modern Office Buildings. Environ. Sci. Technol. 2015, 49 (18), 1101111018.

(70) Basu, R.; Samet, J. M. Relation between elevated ambient temperature and mortality: A review of the epidemiologic evidence. Epidemiol. Rev. 2002, 24 (2), 190-202. 